\title{
Preface: Derrida’s Legacy
}

It is one thing to determine and describe the opinions of philosophers. It is an entirely different thing to talk through [durchsprechen] with them what they are saying, and that means, that of which they speak.

—Martin Heidegger, "What is Philosophy?"

We must begin wherever we are. . . Wherever we are: in a text where we already believe ourselves to be. ${ }^{1}$

When he died in Paris in October 2004, the philosopher Jacques Derrida was a kind of media star. Auditors from all over the world flocked to his lectures and crowded the halls of the École Normale Supérieure, and later those of the École des Hautes Etudes en Sciences Sociales. When he spoke of matters such as the "politics of friendship" or "questions of responsibility," a battery of devices recorded his every word. Derrida, whose writings have been translated into forty languages, held guest-professorships and lectured across the globe, received honorary degrees from twenty-five universities, and gave countless interviews on philosophy and current events. Two films were made about him, which presented the avid public with a portrait of both the thinker and the man himself, in private life.

For a philosopher-even one as prolific as Derrida — such publicity is unusual. The time has passed when philosophy played a leading role in the public sphere. Today, a lot of people are more likely to seek answers to the "big questions" from biology or the neurosciences. Moreover, Derrida's celebrity stands in inverse relation to the difficulty his texts present. While "deconstruction" became a fashionable label for theoretical works in the 1980s and I990s, few people actually bothered reading the texts that received this appellation. Indeed, the attention the media paid to the reception of Derrida's writings often proved a hindrance inasmuch as they gave rise, especially in Germany and the United States, to dismissals of the philosopher as a charlatan and of his concerns as so many rhetorical 
obfuscations; needless to say, discounting Derrida in this way spared his critics the effort of actually reading what he had written.

The book at hand is not meant as a substitute for reading Derrida's texts. Such an intention would be misplaced for at least two reasons: to begin with, the body of texts that appeared under the name of "Jacques Derrida" is too vast to be discussed and commentated-much less summed up-in an introductory work. It includes, depending how one reckons, between twenty-five and forty books, several collections of essays, and countless lectures and articles; and that calculation leaves aside the thousands of pages of unpublished material housed at the Critical Theory Archive of the University of California at Irvine. Moreover, the subject itself makes a synoptic account impossible. Once one has taken to heart the lesson of reading that deconstruction offers-a lesson that constitutes the project above all else-one cannot consider a commentary to provide an adequate substitute, no matter how knowledgeable, learned, and consecrated by academic authority it may be. After Derrida, one should not presume to reformulate what an author has already said (or intended to say) in a more concise, systematic, or clear manner; attempting to do so can only occur at the price of misrecognizing and betraying the object of commentary (cf. below, 2.3).

Accordingly, this slim volume is not meant to replace other introductory works, which have their own merits and rights. Instead, it seeks to provide the reader with a means of finding his or her own way into Derrida's work-by retracing the points of entry that the author herself has found over the years. These modes of approach are ways among others - paths of one particular reading marked by the contingencies of academic and personal history. If it is true that reading means finding "a signifying structure that critical reading should produce" 2 in the first place (see below, 2.2), then no other way of proceeding even exists. Of course, the book was not written without consideration of those for whom it is intended. Above all, it is addressed to students of the humanities, as well as parties within and outside the academy interested in philosophy and politics, who desire "guidance" — explanations of concepts, preconditions, and historical and thematic contexts that are not self-evident. This study seeks to strike a balance between determining and describing "opinions," on the one hand, and "talking them through," on the other. 
In keeping with Derrida's insights, such discussion involves "writing-" or "working through" in the Freudian sense—a mode of inheritance that entails appropriating and passing along what has been handed down. Despite his reputation as a "nihilist" and a "destroyer of tradition," Derrida repeatedly emphasized that we are the heirs of a philosophical and political tradition for which we must assume responsibility. However, he also stressed that the legacy cannot simply be taken as a self-evident matter; it is inherently heterogeneous, contradictory, and divided. "An inheritance is never gathered together," one reads in Specters of Marx (1994),

it is never one with itself. Its presumed unity, if there is one, can consist only in the injunction to reaffirm by choosing. "One must" means one must filter, sift, criticize, one must sort out several different possibles that inhabit the same injunction. [...] If the readability of a legacy were given, natural, transparent, univocal, if it did not call for and at the same time defy interpretation, we would never have anything to inherit from it. We would be affected by it as by a cause-natural or genetic. One always inherits from a secret—which says "read me, will you ever be able to do so?"3

The same holds for Derrida's legacy—an immense corpus of texts that do not yield the unity of a book (or the book-as-an-integrated-whole, an oeuvre). Derrida's writings expound, vary, and abandon themes, which are then taken up in other books and lectures, where they are treated again, further modified, and considered in a new light. In this way, a footnote provides the point of departure for another text, a preface points to a book yet to be written. Such experimentation with textual forms "possesses" a "method" only insofar as it actively negates the classical conception of philosophy as a series of deductive steps leading to the recognition and demonstration of the truth (for reasons that will be discussed).

Derrida's work does not yield a system of theses that one might reconstruct in keeping with the logic of a development from point A to point B. Rather, it resembles an open network of references and correspondences- $\mathrm{a}$ "fabric of traces" in a space of writing and thinking where readings overlap, motifs echo each other, and lines of interpretation intersect, change direction, and then diverge. In a certain sense, this space of writing and thinking occupies the space of the tradition whose inheritor Derrida understood himself to be, into which he inscribed his own works - above all, by a process of reading. For Derrida, reading (reading as 
inheriting, and inheriting as transformative transmission) represents philosophical praxis tout court. For this reason, the book at hand considers it essential to explain what reading, in the deconstructive sense of the word, means. It lies in the nature of the matter (insofar as the author of this book follows the deconstructive project) that this can only occur by reading, and this is why the following offers more exemplary readings of texts than attempts to summarize them (i.e., write about or "describe" "opinions").

At the same time, the study represents a compromise with classical, propaedeutic form inasmuch as it respects chronology. After an introductory chapter on the philosophical-historical preconditions of deconstruction, the readings follow, for the most part, the sequence in which Derrida's texts were written or published. Proceeding in this fashion makes it possible to discern a certain succession of themes and a shift in focus. Derrida's writings up to the I980s are devoted above all to the concepts of the sign, writing, text, and difference, which are displaced in order to deconstruct the metaphysics of presence. The texts of the late $1980 \mathrm{os}$ until Derrida's death, on the other hand, more frequently address ethical and political topics, which are explored in conjunction with the undeconstructible premises of deconstruction (cf. Third Approach). How and why the critique of language is inseparable from ethics- how and why the deconstruction of ontology connects with the project of thinking a "democracy to come" - will also be our concern.

A word about what is not treated on the following pages is in order. Among Derrida’s "main" works, this includes Glas (1974), his engagement with Hegel and Jean Genet, and two books that contribute to (the critique of) aesthetics and the philosophy of the body: Truth in Painting (1978) and On Touching-Jean-Luc Nancy (2000). Likewise, Derrida's discussion of Husserl, the focus of his first publications, is treated only in passing. Finally, the matter of deconstruction and psychoanalysis would have deserved a chapter of its own, as would the topic of deconstruction and literature (even though attention is paid to the significance of both for situating deconstruction in the contemporary theoretical landscape). The omissions stem from limitations of space, as well as from personal decisions that deem some matters more directly relevant than others. Among the different possibilities inhering in Derrida's injunction, I have given preference to those that seem more likely than others to have an effect 
extending beyond the borders of the academy-those that entail changes in our ways of thinking and acting. In this, I follow Derrida's own articulation of the role of deconstruction, which

would like, in order to be consistent with itself, not to remain enclosed in purely speculative, theoretical, academic discourses but rather ... to aspire to something more consequential, to change things and to intervene in an efficient and responsible, though always, of course, very mediated way, not only in the profession but in what one calls the cité, the polis, and more generally the world. ${ }^{5}$

Whether this, after the author's death, will prove possible, depends most of all on the readiness of those who have survived Derrida to inherit from him, read his writings, work through them, critique them, and reaffirm his legacy by choosing.

Even if such a decision, in the final instance, must be undertaken independently, an introduction may still help one to find "one's own way." The undertaking is not easy, especially from my own, German, perspective. In Germany, the university system never paid much heed to structuralism, poststructuralism, or psychoanalysis. In Germany as well as in the US, linguists read everyone but Saussure, psychologists read everyone but Freud, and academic philosophers have never been able to make much of Derrida (among other reasons, because of omissions practiced by their colleagues in the aforementioned fields). Not much has changed since I was a student in the 1980 - - the buzz in the media surrounding Derrida as a public intellectual, now as then, amounts to deafness and resistance to the matters that concerned him.

It reflects my own interpretation when I describe the reasons underlying deconstruction as the attempt to find a responsible form of philosophizing "after Auschwitz," to paraphrase Theodor W. Adorno. Derrida does not explicitly voice this intention anywhere in his work (except, perhaps, somewhere in his unedited papers), and he never mentioned Adorno more than in passing (and that, according to reliable sources, mainly in the late, still-unpublished seminars). The differences between Adorno and Derrida are, of course, significant. In a word, Adorno views the "nonidentical" as an unredeemed or unreconciled form of identity; for Derrida - who refers to it by the name of differance-it represents a form of auto-affection that, while irreducible, must be affirmed. All the same, it is no accident that a form of connectivity exists between Critical Theory 


\section{Preface}

and deconstruction, for both projects seek to explore the consequences of twentieth-century (European) catastrophe. That is, both projects seek to assume this inheritance-especially this inheritance-in view of a future in which nothing of the like should occur again.

We are not free to reject this responsibility. Indeed, as Derrida says, we are responsible to past and future alike, whether we wish to be and whether we know it, or not. It is this condition of obligation that makes it necessary to read. And so, wherever we are, we must begin there. Somewhere, wherever we are: in a text where we already believe ourselves to be-for example, in this one, here. 
POLITICS OF DECONSTRUCTION 
